University of Nebraska - Lincoln

DigitalCommons@University of Nebraska - Lincoln

\title{
Salinity and Sodicity Changes under Irrigated Alfalfa in the Northern Great Plains
}

\author{
Brian J. Wienhold \\ USDA-ARS, Brian.Wienhold@ars.usda.gov \\ Todd P. Trooien \\ USDA-ARS
}

Follow this and additional works at: https://digitalcommons.unl.edu/usdaarsfacpub

Wienhold, Brian J. and Trooien, Todd P., "Salinity and Sodicity Changes under Irrigated Alfalfa in the Northern Great Plains" (1995). Publications from USDA-ARS / UNL Faculty. 1215.

https://digitalcommons.unl.edu/usdaarsfacpub/1215

This Article is brought to you for free and open access by the U.S. Department of Agriculture: Agricultural Research Service, Lincoln, Nebraska at DigitalCommons@University of Nebraska - Lincoln. It has been accepted for inclusion in Publications from USDA-ARS / UNL Faculty by an authorized administrator of DigitalCommons@University of Nebraska - Lincoln. 


\title{
Salinity and Sodicity Changes under Irrigated Alfalfa in the Northern Great Plains
}

\author{
Brian J. Wienhold* and Todd P. Trooien
}

\begin{abstract}
Insufficient water is the greatest limitation to crop production and choice of crops grown in the Northern Great Plains. Supplemental irrigation can overcome this limitation. Uncertainties about the drainage capacity of fine-textured subsoils and the effect of irrigation on soil properties has impeded irrigation development. In this study we quantified salinity changes in soils with fine-textured subsoils receiving a range of irrigation treatments. Alfalfa (Medicago sativa L.) was planted in 18 nonweighing lysimeters at two sites having fine-textured subsoils. Irrigation was applied at three levels so that irrigation plus precipitation equaled either one, two, or three times the calculated evapotranspiration rate using two water qualities (electrical conductivity of irrigation water $\left[E C_{1}\right] 0.1 \mathrm{~S} \mathrm{~m}^{-1}$, sodium adsorption ratio of irrigation water [SAR] 4; or $E C_{i} 0.34 \mathrm{~S} \mathrm{~m}^{-1}, S_{i} R_{i}$ 16). Changes in the electrical conductivity of saturated soil extracts $\left(E C_{e}\right)$ and the sodium adsorption ratio of sat urated soil extracts $\left(\mathbf{S A R}_{\mathbf{e}}\right)$ were determined from soil cores collected to a depth of $1.5 \mathrm{~m}$ nine times between the years of 1984 and 1993 . Averaged across irrigation levels, the profile-averaged $\mathrm{EC}_{\mathrm{e}}$ increased from 0.03 to $0.12 \mathrm{~S} \mathrm{~m}^{-1}$ and the $\mathrm{SAR}_{\mathrm{e}}$ increased from 1 to 6 in lysimeters receiving the $0.1 \mathrm{~S} \mathrm{~m}^{-1}$ water. In lysimeters receiving the $0.34 \mathrm{~S} \mathrm{~m}^{-1}$ water, the profile-averaged $\mathrm{EC}_{\mathrm{e}}$ increased from 0.03 to $0.23 \mathrm{~S} \mathrm{~m}^{-1}$ and the $S_{A R}$ increased from 1 to 11. Salinity exhibited seasonal fluctuations. Changes in sodicity were persistent, exhibiting little seasonal variation. Supplemental irrigation of alfalfa is a viable management option in the Northern Great Plains when irrigation water quality is not a problem.
\end{abstract}

$\mathrm{S}$ PPLEMENTAL IRRIGATION is a management strategy that can be used by producers in the Northern Great Plains to meet crop moisture needs during periods of below-normal precipitation or to grow crops that require more water than is normally available. Supplemental irrigation is economical in certain areas of North Dakota (Leitch et al., 1991) but remains underutilized by producers. Uncertainty about the drainage capacity of many fine-textured or stratified soils and the effects irrigation will have on physical and chemical properties of these soils are reasons producers may be unwilling to invest in an irrigation system.

Soils are classified as nonirrigable when the subsoil has a hydraulic conductivity $<20 \%$ of the weighted hydraulic conductivity of the overlying soil layers and the slowly permeable layer is within $1.8 \mathrm{~m}$ of the surface (U.S. Department of Interior, Bureau of Reclamation, 1993). Adequate drainage capacity has been demonstrated in situ, using large $(2.5 \mathrm{~m}$ square by $2.3 \mathrm{~m}$ deep) nonweighing lysimeters, for two sites having fine-textured subsoils classified as nonirrigable using U.S. Bureau of Reclamation criteria (Doering et al., 1986; Trooien and Reichman, 1990). The drainage capacity of these soils was sufficient to prevent development of a perched water table above the fine-textured subsoil even when irrigation

USDA-ARS, Northern Great Plains Research Lab., P.O. Box 459, Mandan, ND 58554-0459. Received 28 Nov. 1994. *Corresponding author (weinholb@ars.usda.gov).

Published in Soil Sci. Soc. Am. J. 59:1709-1714 (1995) water was applied at rates three times the ET (Trooien and Reichman, 1993). In addition, 280000 ha of land with similar soils in southern Alberta have been irrigated for $>50 \mathrm{yr}$ with few drainage problems (Chang et al., 1985).

Adequate drainage allows application of irrigation water in excess of that needed by the crop so that salts are leached out of the root zone and salinization of the soil does not occur. Most studies dealing with salinization associated with irrigation have been conducted in $\mathrm{Cl}^{-}$. dominated systems. Most soil and groundwater systems in the Northern Great Plains are not $\mathrm{Cl}^{-}$dominated but rather contain proportionately large amounts of $\mathrm{SO}_{4}^{2-}$, $\mathrm{HCO}_{3}^{-}$, and $\mathrm{CO}_{3}^{2-}$ (Prunty et al., 1991).

A greenhouse lysimeter study using four commonly irrigated North Dakota soils and six waters (distilled water and five with a range of chemical compositions similar to those of groundwater in North Dakota) measured the yield response of alfalfa (Prunty et al., 1991) and quantified changes in soil chemical and physical properties (Costa et al., 1991). Little drainage was allowed as water inputs were such that drainage from the lysimeters was $<2 \%$ of the applied water. The total amount of water applied was similar to what would be applied during17 yr under field conditions. A seventh treatment alternated irrigation with saline water and distilled water to simulate the effect of precipitation during the growing season. Alfalfa yields decreased 30 to $60 \%$ in all treatments by the end of the experiment (Prunty et al., 1991). Substantial amounts of salts were deposited in the soil profile in these treatments. Precipitation of $\mathrm{Ca}$ and $\mathrm{Mg}$ salts resulted in an increase in $\mathrm{SAR}_{\mathrm{c}}$ (Costa et al., 1991). The effects of irrigation on soil chemical properties in the field have not been reported for the Northern Great Plains. The objectives of this study were to quantify soil profile salinity changes at two sites with fine-textured subsoils when these soils were irrigated with two qualities of irrigation water applied at three rates.

\section{MATERIALS AND METHODS}

Two Northern Great Plains sites were used; the Menoken township site (T139N, R78W, Sec. 19, SE 1/4) (Doering et al., 1986) and the Naughton township site (T140N, R79W, Sec. 35, SW 1/4) (Trooien and Reichman, 1990). These sites are located in central North Dakota, $50 \mathrm{~km}$ east of Bismarck in Burleigh County. Soils at the Menoken site are Lihen sandy loam (sandy, mixed Entic Haploboroll), Roseglen loam (fineloamy, mixed Pachic Haploboroll), and Parshall (coarseloamy, mixed Pachic Haploboroll) (Table 1). These soils developed on aeolian-lacustrine sediments deposited over fine lacustine sediments. Soil structure at the Menoken site is massive or single grained and is similar throughout the sampled profile (M.D. Sweeney, 1982, unpublished data). Soils at the Naughton site are Falkirk loam (fine-loamy, mixed Pachic

Abbreviations: EC, electrical conductivity; SAR, sodium adsorption ratio; ET, evapotranspiration. 
Haploboroll) and Bowbells loam (fine-loamy, mixed Pachic Argiboroll) (Table 1). These soils developed on slope-worked alluvium deposited on till. At the Naughton site, soil structure in the surface layers of the profile is weak to moderate coarse subangular blocky or prismatic and at lower layers is moderate to strong coarse subangular blocky or prismatic (S.C. Ekart, 1994, unpublished data). Soil texture becomes finer with depth at both sites (Table 1). Soils at both sites are well drained.

Each site had alfalfa planted in 18 nonweighing lysimeters ( $2.5 \mathrm{~m}$ square and $2.3 \mathrm{~m}$ deep). The undisturbed lysimeters retained the natural drainage characteristics of the soil profile (Doering et al., 1986; Trooien and Reichman, 1990). Three irrigation water levels were used. These irrigation levels were calculated so that precipitation plus irrigation would be one (1ET), two (2ET), or three (3ET) times the calculated JensenHaise alfalfa evapotranspiration (Jensen et al., 1970) with weekly adjustments similar to a crop coefficient from Lundstrom and Stegman (1983). Two irrigation water qualities were used. Water from the Heart River, a tributary of the Missouri River, had an $\mathrm{EC}_{\mathrm{i}}$ of $0.1 \mathrm{~S} \mathrm{~m}^{-1}$ and a $\mathrm{SAR}_{\mathrm{i}}$ of 4 . Water similar to shallow groundwater in North Dakota with an $\mathrm{EC}_{\mathrm{i}}$ of 0.34 $\mathrm{S} \mathrm{m}^{-1}$ and a SAR $\mathrm{S}_{\mathrm{i}}$ of 16 was produced by adding $\mathrm{NaCl}$ and $\mathrm{CaCl}_{2}$ (ratio of $6: 1$ by weight) to the Heart River water. The experiment was replicated three times, with treatments assigned to the lysimeters in a randomized complete block design. Irrigation was generally not needed prior to 1 July and was discontinued after the final harvest in September each year. Alfalfa (Pioneer 524) was established at the Menoken site in 1984 and at the Naughton site in 1986. Both stands were lost during the winter of 1988 and were reestablished (cv. Vernal) in 1989. During the establishment years, good quality irrigation water was used in all lysimeters.

Soil cores to a depth of $1.5 \mathrm{~m}$ were collected periodically during the study. Two cores were collected from each lysimeter, sectioned into six increments $(0-0.15,0.15-0.3,0.3-0.6$, $0.6-0.9,0.9-1.2$, and $1.2-1.5 \mathrm{~m})$, and composited. Cores were collected at the Menoken site in the fall of 1984, fall of 1989 , and spring and fall of 1992 . Cores were collected at the Naughton site in the fall of 1986, 1991, 1992, and 1993. Soil cores to a depth of $1.8 \mathrm{~m}$ were collected from each lysimeter at the Naughton site in the fall of 1989 . Because a different sampling regime was used in the fall of 1989 at the Naughton site, these data were not used in the statistical analysis. However, the data are presented graphically along with the results from the other sampling periods. A saturated paste extract was obtained for each soil sample and the $\mathrm{EC}_{e}$ (Rhoades, 1982) and SAR $_{e}$ (U.S. Salinity Laboratory Staff, 1954) determined.

The effect of irrigation amount and irrigation water quality on $\mathrm{EC}_{\mathrm{e}}$ and $\mathrm{SAR}_{\mathrm{e}}$ were measured repeatedly for several years for each lysimeter. Because $\mathrm{EC}_{e}$ and $\mathrm{SAR}_{\mathrm{e}}$ for a given soil depth were not independent of other depths, a repeatedmeasures analysis of variance appropriate for a randomized complete block design was used (SAS Institute, 1990).

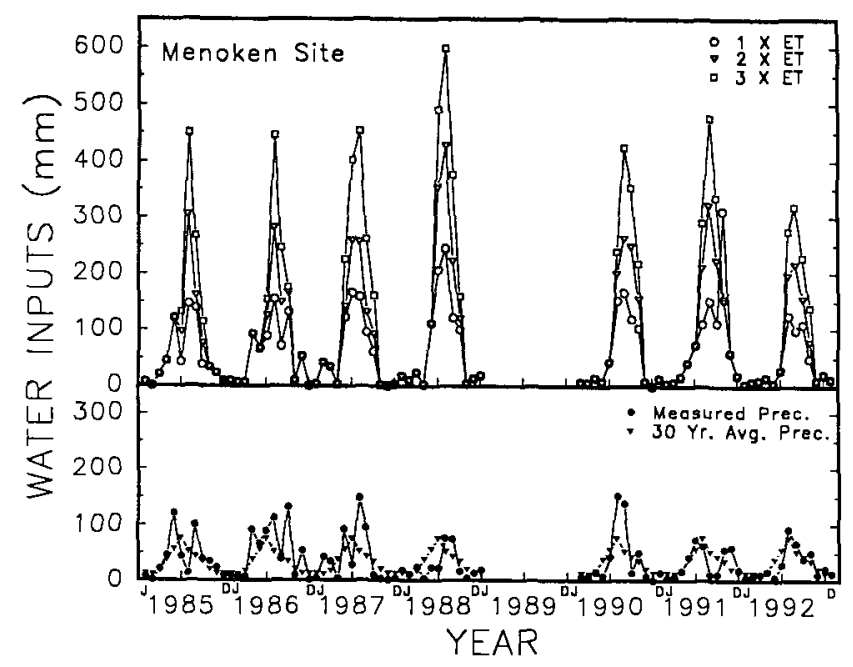

Fig. 1. Monthly precipitation (lower) and total (upper) water inputs for lysimeters at the Menoken site. Monthly precipitation is compared with 30-yr average. Total water inputs are the sum of irrigation and precipitation.

\section{RESULTS \\ Menoken Site}

Water inputs for the lysimeters were highest in 1988 when hot, dry conditions in the spring resulted in high ET (Fig. 1). Lowest water inputs occurred during 1992, a year that had cool temperatures and near-normal precipitation (Fig. 1). Total water inputs during the remaining $5 \mathrm{yr}$ were similar and averaged $730 \mathrm{~mm}$ for lysimeters receiving the 1ET irrigation treatment, $1040 \mathrm{~mm}$ for lysimeters receiving the 2ET irrigation treatment, and $1390 \mathrm{~mm}$ for lysimeters receiving the 3ET irrigation treatment.

The initial (1984) $\mathrm{EC}_{\mathrm{e}}$ at the Menoken site was 0.03 $S \mathrm{~m}^{-1}$ in all of the lysimeters and did not change with depth (Fig. 2). By the fall of 1989 the $\mathrm{EC}_{\mathrm{e}}$ in a given lysimeter had increased to a value very close to that of the irrigation water received by that lysimeter and was similar at all depths within a lysimeter (Fig. 2). In 1989 the similarity in $\mathrm{EC}_{\mathrm{e}}$ throughout the sampled profile, even at $1 \mathrm{ET}$, and the similarity across irrigation levels for a given water quality suggests that the hydraulic conductivity through this soil is sufficient to remove salt at a rate exceeding the rate of salt precipitation, resulting in little salt accumulation within the sampled profile. In addition, the drainage capacity of the subsoil at this site is sufficient to prevent the accumulation of water and salts. These characteristics allow continuous leaching of salts through the profile.

By the spring of 1992 the $\mathrm{EC}_{\mathrm{e}}$ had decreased to 0.06

Table 1. Soil texture as a function of depth for lysimeters at the Menoken and Naughton sites.

\begin{tabular}{|c|c|c|c|c|c|}
\hline \multirow[b]{2}{*}{ Depth } & \multicolumn{3}{|c|}{ Menoken site } & \multicolumn{2}{|c|}{ Naughton site } \\
\hline & Lihen sandy loam & Parshall & Roseglen loam & Falkirk loam & Bowbells loam \\
\hline $\begin{array}{l}0-0.15 \\
0.15-0.5 \\
0.5-0.9 \\
0.9-1.2 \\
1.2-1.5 \\
\end{array}$ & $\begin{array}{l}\text { Loamy sand } \\
\text { Sand } \\
\text { Sand } \\
\text { Silty clay } \\
\text { Silty clay } \\
\end{array}$ & $\begin{array}{l}\text { Loamy sand } \\
\text { Sand } \\
\text { Sand } \\
\text { Silty clay } \\
\text { Silty clay } \\
\end{array}$ & $\begin{array}{l}\text { Loam } \\
\text { Loam } \\
\text { Silt loam } \\
\text { Loamy fine sand } \\
\text { Silty clay } \\
\end{array}$ & $\begin{array}{l}\text { Loam } \\
\text { Silt loam } \\
\text { Silt loam } \\
\text { Silt loam } \\
\text { Clay loam } \\
\end{array}$ & $\begin{array}{l}\text { Loam } \\
\text { Clay loam } \\
\text { Clay loam } \\
\text { Clay loam } \\
\text { Clay loam } \\
\end{array}$ \\
\hline
\end{tabular}




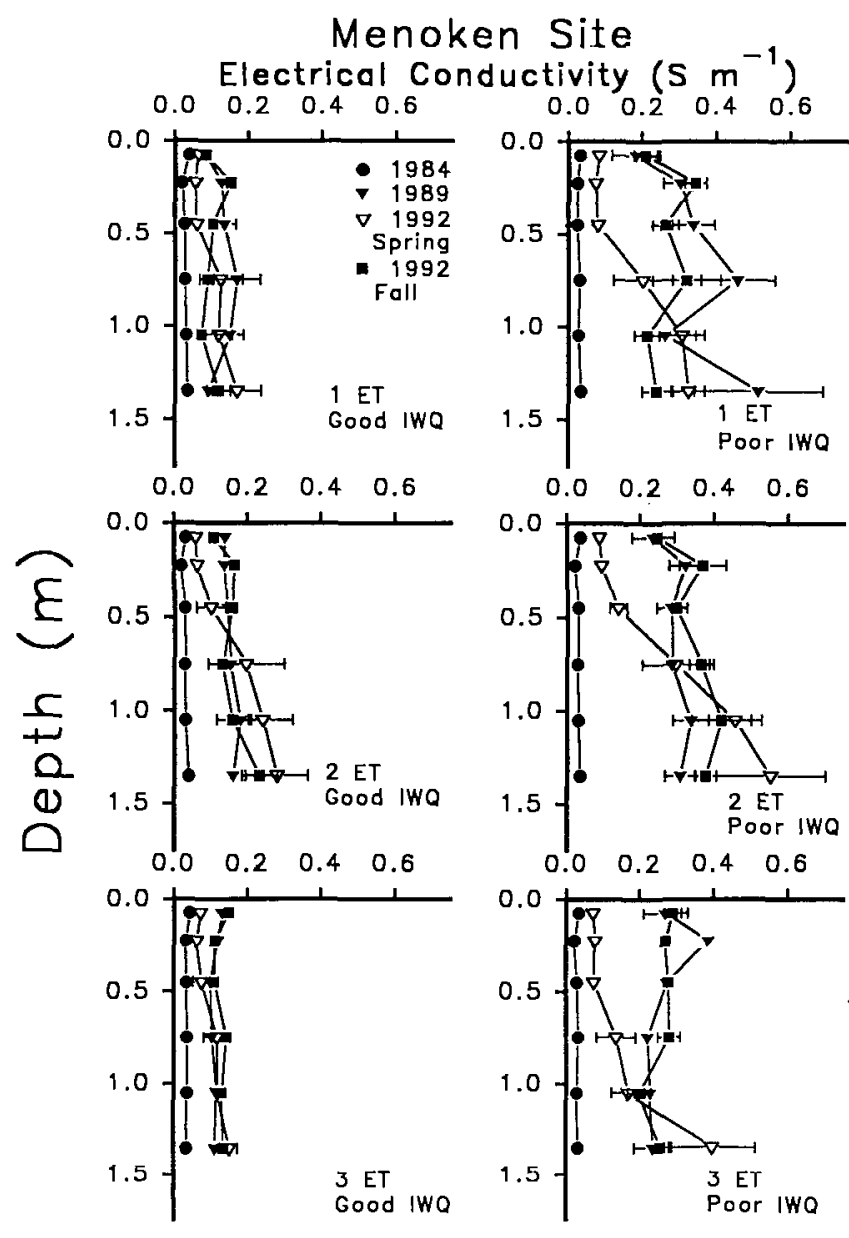

Fig. 2. Saturated paste extract electrical conductivity (EC) as a function of soil depth for lysimeters at the Menoken site receiving water inputs equal to one, two, and three times the calculated evapotranspiration (ET) rate as either good irrigation water quality (good IWQ: $\mathrm{EC}=0.1 \mathrm{~S} \mathrm{~m}^{-1}$ and sodium adsorption ratio [SAR] $=4$ ) or poor irrigation water quality (poor IWQ: $\mathrm{EC}=0.34 \mathrm{~S}$ $\mathbf{m}^{-1}$ and SAR $=16$ ).

$\mathrm{S} \mathrm{m}^{-1}$ in the 0 - to $0.5-\mathrm{m}$ depth in all of the lysimeters, approaching the initial $\mathrm{EC}_{\mathrm{e}}$ value. Below $0.5 \mathrm{~m}$, the $\mathrm{EC}_{\mathrm{e}}$ increased to a value approaching or slightly exceeding $E C_{i}\left(E C_{e}\right.$ value of the previous fall). This pattern suggests that leaching by rain, in the fall and spring, and melting snow removed salts from the surface layers and from the root zone, depositing them lower in the soil profile (Fig. 2). This pattern was most evident in lysimeters receiving the $0.34 \mathrm{~S} \mathrm{~m}^{-1}$ irrigation water. By the fall of 1992 the $\mathrm{EC}_{\mathrm{e}}$ had increased and was similar to the $\mathrm{EC}_{\mathrm{i}}$ at all sampled depths (Fig. 2). The change in $\mathrm{EC}_{\mathrm{e}}$ exhibited during 1992 suggests that the salt status of this soil is easily manipulated. Application of poor quality water or insufficient amounts of water to leach salts would result in a rapid increase in $E_{e}$. Salt buildup would probably occur only in years of low precipitation and insufficient leaching. Rehabilitation of these soils should also be rapid as long as the natural drainage was not altered.

The initial $\mathrm{SAR}_{\mathrm{e}}$ at the Menoken site was 1 in all of the lysimeters (Fig. 3). By 1989 the $\mathrm{SAR}_{\mathrm{e}}$ had increased in the upper $0.5 \mathrm{~m}$ of the sampled profile and approached

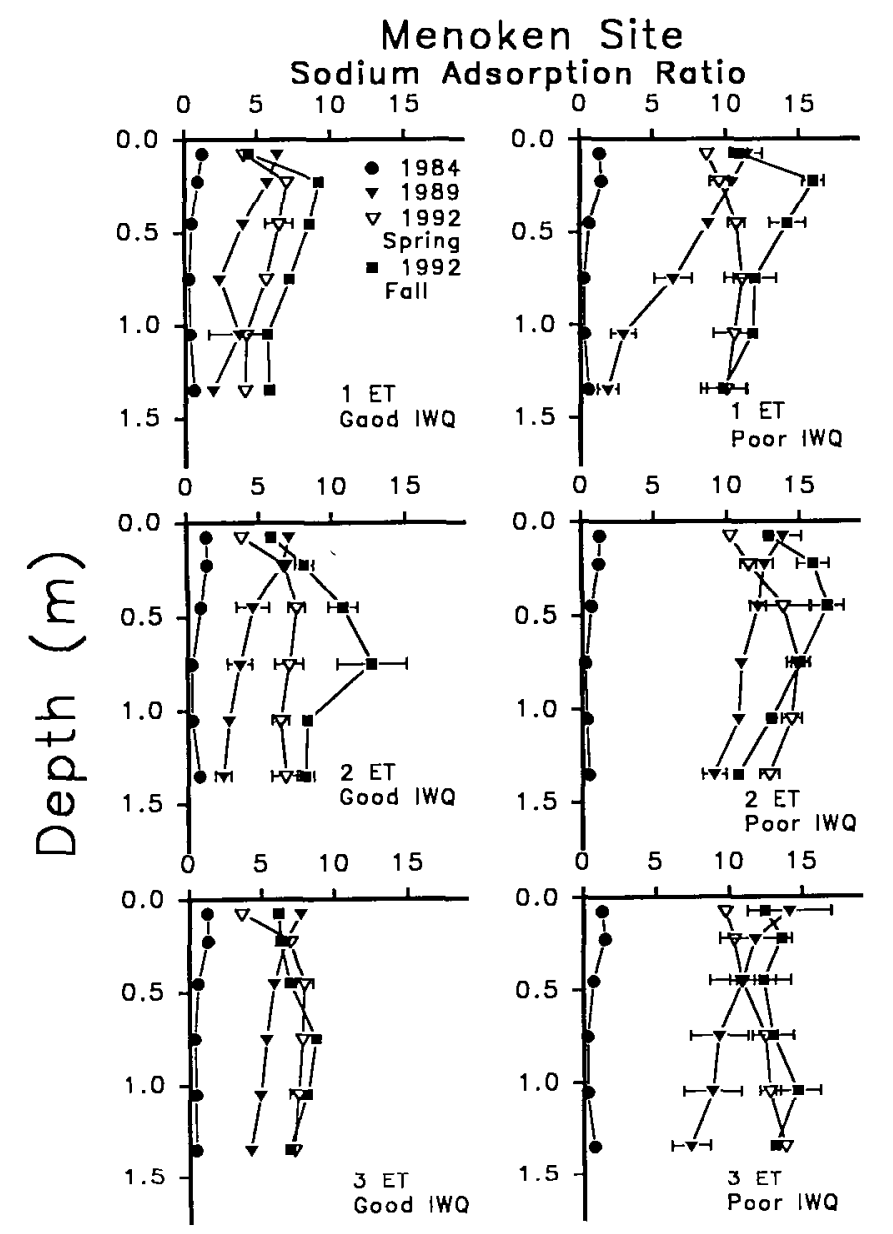

Fig. 3. Saturated paste extract sodium adsorption ratio (SAR) as a function of soil depth for lysimeters at the Menoken site receiving water inputs equal to one, two, and three times the calculated evapotranspiration (ET) rate as either good irrigation water quality (good IWQ: electrical conductivity $[E C]=0.1 \mathrm{~S} \mathrm{~m}^{-1}$ and $\mathrm{SAR}=$ 4) or poor irrigation water quality (poor IWQ: $\mathrm{EC}=0.34 \mathrm{~S} \mathrm{~m}^{-1}$ and SAR $=16$ ).

the $\mathrm{SAR}_{\mathrm{i}}$ in lysimeters receiving the $0.1 \mathrm{~S} \mathrm{~m}^{-1}$ water but was slightly less than the $\mathrm{SAR}_{\mathrm{i}}$ in lysimeters receiving the $0.34 \mathrm{~S} \mathrm{~m}^{-1}$ water. The SAR decreased with depth, with the magnitude of the decrease being dependent on irrigation amount. At the 1ET level of irrigation, the decline with depth was rapid and the $\mathrm{SAR}_{e}$ at the lowest depth was similar to the initial value (Fig. 3). At the 3ET level of irrigation, the decline was much more gradual and the $\mathrm{SAR}_{\mathrm{e}}$ changed little with depth. The change in $S A R_{e}$ with depth for lysimeters receiving the 2ET level of irrigation was similar to that of the 3ET level of irrigation (Fig. 3).

By the spring of 1992 the $\mathrm{SAR}_{\mathrm{e}}$ was lowest in the 0to $0.15-\mathrm{m}$ depth of all the lysimeters increasing with depth to a value of 4 (similar to the $S_{A} R_{i}$ ) in lysimeters receiving the $0.1 \mathrm{~S} \mathrm{~m}^{-1}$ water and to a value of 15 (slightly less than the $\mathrm{SAR}_{\mathrm{i}}$ ) in lysimeters receiving the $0.34 \mathrm{~S} \mathrm{~m}^{-1}$ water (Fig. 3). The decline at the surface may be the result of leaching by fall and spring rains and melting of snow. The similarity in $\mathrm{SAR}_{\mathrm{e}}$ with depth below $0.5 \mathrm{~m}$ suggests that $7 \mathrm{yr}$ of irrigation had leached the salts through the lysimeters, even at 1ET of irrigation. 
Table 2. Results ( $P$ values) of the repeated-measures analysis of variance for saturated paste extract electrical conductivity $\left(\mathrm{EC}_{\mathrm{e}}\right)$ and sodium adsorption ratio $\left(\mathbf{S A R}_{\mathrm{e}}\right)$.

\begin{tabular}{|c|c|c|c|c|}
\hline & \multicolumn{2}{|c|}{ Menoken site } & \multicolumn{2}{|c|}{ Naughton site } \\
\hline & $\mathrm{EC}_{\mathrm{e}}$ & SAR, & $\mathrm{EC}_{\mathrm{e}}$ & $\mathbf{S A R}_{\mathrm{e}}$ \\
\hline Year & 0.0001 & 0.0001 & 0.0001 & 0.0001 \\
\hline Depth & 0.0001 & 0.0001 & 0.0001 & 0.0001 \\
\hline Irrigation amount (IRR) & 0.0132 & 0.0009 & 0.0344 & 0.0001 \\
\hline Water quality (WQ) & 0.0001 & 0.0001 & 0.0001 & 0.0001 \\
\hline Year $\times$ depth & 0.0001 & 0.0001 & 0.0001 & 0.0001 \\
\hline Year $\times$ IRR & 0.0023 & 0.0868 & 0.0010 & 0.0011 \\
\hline Year $\times W Q$ & 0.0001 & 0.0001 & 0.0001 & 0.0001 \\
\hline Depth $\times$ IRR & 0.0001 & 0.0001 & 0.0152 & 0.0001 \\
\hline Depth $\times$ WQ & 0.0008 & 0.0818 & 0.1487 & 0.0001 \\
\hline IRR $\times$ WQ & 0.3973 & 0.1067 & 0.1191 & 0.1657 \\
\hline Year $\times$ depth $\times$ IRR & 0.0016 & 0.0008 & 0.0163 & 0.0001 \\
\hline Year $\times$ depth $\times$ WQ & 0.0001 & 0.0001 & 0.0274 & 0.0001 \\
\hline Year $\times$ IRR $\times$ WQ & 0.3027 & 0.2573 & 0.5015 & 0.8558 \\
\hline Depth $\times$ IRR $\times$ WQ & 0.1463 & 0.1905 & 0.8562 & 0.0741 \\
\hline Year $\times$ depth $\times$ IRR $\times$ WQ & 0.2862 & 0.1262 & 0.9996 & 0.3348 \\
\hline
\end{tabular}

At 2ET and 3ET levels of irrigation, the $\mathrm{SAR}_{e}$ in the fall of 1992 was lower in the 0 - to $0.15-\mathrm{m}$ depths than in the 0.15- to $0.5-\mathrm{m}$ depths. Below $0.5 \mathrm{~m}$ the $S A R_{e}$ declined slightly and approached that of 1989 (Fig. 3). These results are probably the result of leaching of salts from the surface and concentrating of salts due to water extraction by the crop in the $0.15-$ to 0.5 -m depth (Fig. 3).

Changes in $\mathrm{EC}_{e}$ (Fig. 2) and $\mathrm{SAR}_{e}$ (Fig. 3) values at the Menoken site resulted in significant year $\times$ depth $x$ level of irrigation, and year $x$ depth $x$ water quality interactions in the statistical analysis (Table 2). Changes in salinity of these soils were dependent on amount and quality of irrigation water applied (Table 2). The magnitude of the change in salinity varied among sampling periods, due to yearly differences in climatic conditions, and with depth, as a result of heterogeneity within the profile. The variation with depth was greatest for spring 1992 when overwinter water inputs leached salts from the 0 - to $0.15-\mathrm{m}$ soil depth but were insufficient to leach salts from the entire $1.5-\mathrm{m}$ profile.

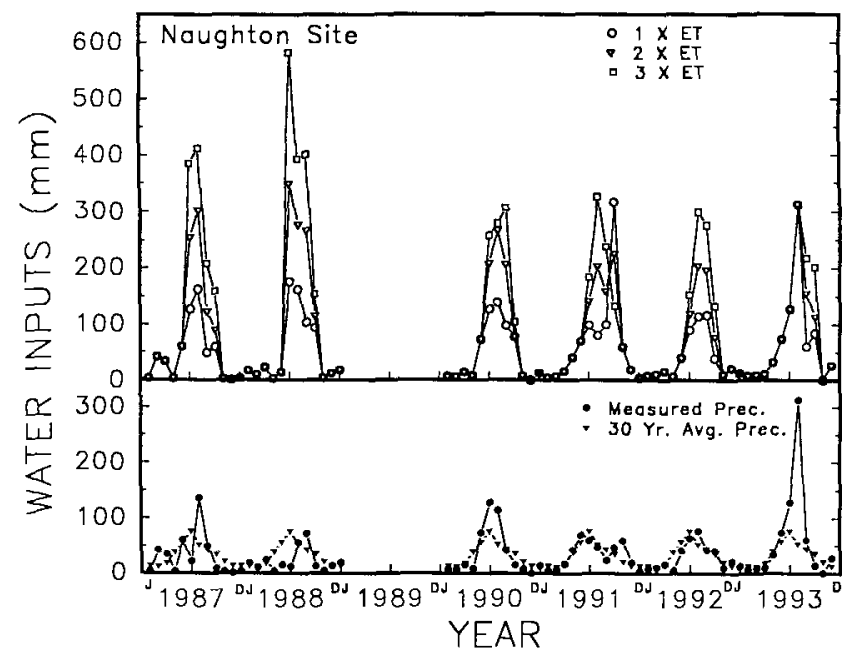

Fig. 4. Monthly precipitation (lower) and total (upper) water inputs for lysimeters at the Naughton site. Monthly precipitation is compared with 30-yr average. Total water inputs are the sum of irrigation and precipitation.

\section{Naughton Site}

Water inputs were slightly higher in 1987 , the result of below-normal precipitation and warm temperatures in the spring, and much higher in 1988 than in the remaining $4 \mathrm{yr}$ (Fig. 4). Precipitation accounted for essentially all water inputs in 1993, the result of higher than average precipitation and cool temperatures during much of the year (Fig. 4). Total water inputs for 1990, 1991, and 1992, when temperatures and precipitation were near normal, averaged $525 \mathrm{~mm}$ for lysimeters receiving the $1 E T$ irrigation treatment, $755 \mathrm{~mm}$ for lysimeters receiving the $2 \mathrm{ET}$ irrigation treatment, and 955 $\mathrm{mm}$ for lysimeters receiving the 3ET irrigation treatment.

The initial $\mathrm{EC}_{\mathrm{e}}$ at the Naughton site was $0.03 \mathrm{~S} \mathrm{~m}^{-1}$ in all of the lysimeters (Fig. 5). By 1989, after receiving irrigation treatments for $3 \mathrm{yr}$, the $\mathrm{EC}_{\mathrm{e}}$ increased in all of the lysimeters. This increase was greater in lysimeters receiving the $0.34 \mathrm{~S} \mathrm{~m}^{-1}$ irrigation water than in lysimeters receiving the $0.1 \mathrm{~S} \mathrm{~m}^{-1}$ irrigation water and in lysimeters receiving the 1ET level of irrigation (Fig. 5). At 2ET and 3ET levels of irrigation, salts were leached

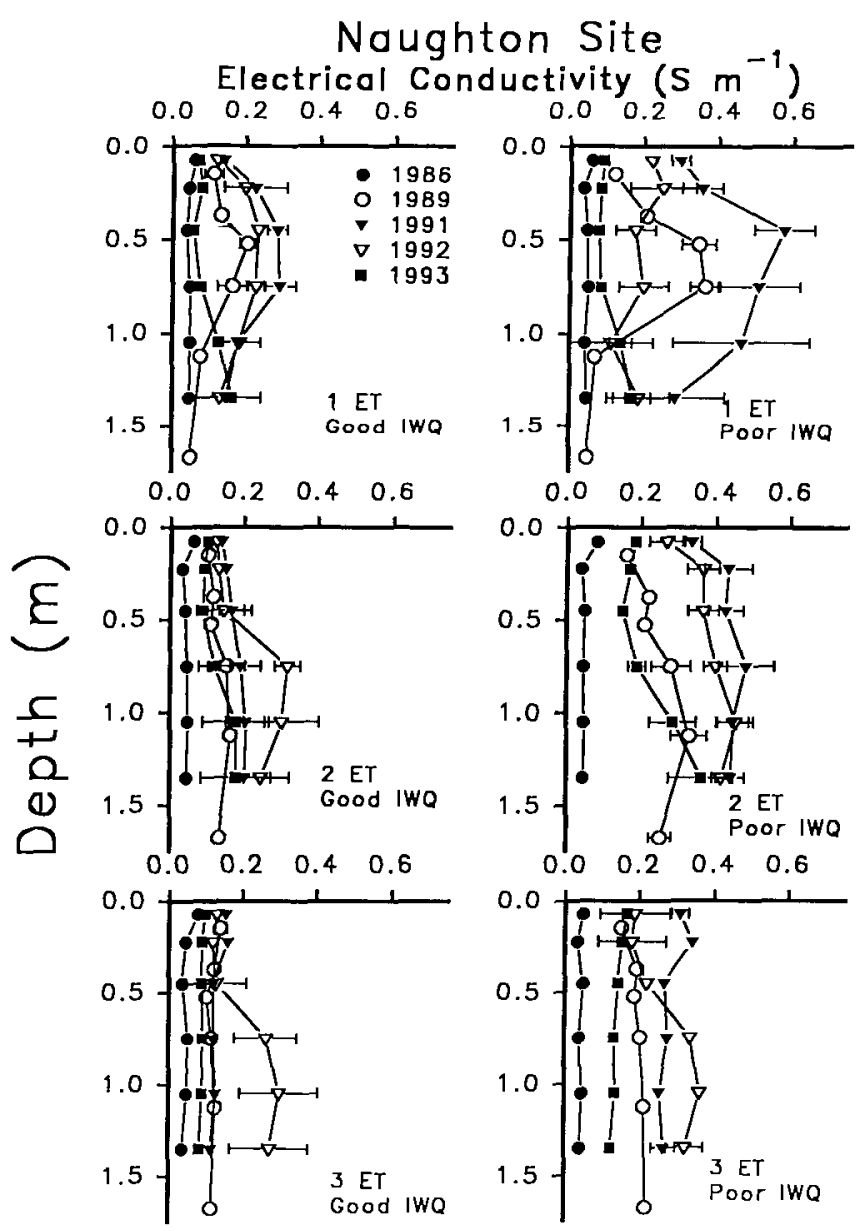

Fig. 5. Saturated paste extract electrical conductivity (EC) as a function of soil depth for lysimeters at the Naughton site receiving water inputs equal to one, two, and three times the calculated evapotranspiration (ET) rate as either good irrigation water quality (good IWQ: $\mathrm{EC}=0.1 \mathrm{~S} \mathrm{~m}^{-1}$ and sodium adsorption ratio [SAR] $=4$ ) or poor irrigation water quality (poor IWQ: $E C=0.34 \mathrm{~S}$ $\mathrm{m}^{-1}$ and $\mathrm{SAR}=16$ ). 
from the 0 - to $1.0-\mathrm{m}$ soil depths and the increase in $\mathrm{EC}_{\mathrm{e}}$ was reduced. At the 1ET level of irrigation, salts accumulated in the upper $1.0 \mathrm{~m}$ of the soil profile, while below this the $\mathrm{EC}_{\mathrm{e}}$ was similar to the initial values (Fig. 5). At $2 E T$ and $3 E T$ levels of irrigation, the $E_{e}$ increased throughout the soil profile compared with initial values.

By 1991, after receiving the irrigation treatments for $5 \mathrm{yr}$, the $\mathrm{EC}_{\mathrm{e}}$ had increased compared with 1989 (Fig. $5)$. This increase was more pronounced in lysimeters receiving the $0.34 \mathrm{~S} \mathrm{~m}^{-1}$ irrigation water than in lysimeters receiving the $0.34 \mathrm{~S} \mathrm{~m}^{-1}$ irrigation water. The increase was greatest in lysimeters receiving 1ET of irrigation where the $\mathrm{EC}_{\mathrm{e}}$ was greater than that of the irrigation water, and least in lysimeters receiving $2 \mathrm{ET}$ or $3 \mathrm{ET}$ of irrigation where the $\mathrm{EC}_{\mathrm{e}}$ was similar to $\mathrm{EC}_{\mathrm{i}}$ (Fig. 5).

Precipition in 1993 was substantially above normal and irrigation inputs were low (Fig. 4). This resulted in the addition of less salt to the lysimeters and a substantial leaching of existing salts. By 1993 the $\mathrm{EC}_{e}$ declined in the upper portion of the profile and approached the initial $\mathrm{EC}_{\mathrm{e}}$ in many of the treatments (Fig. 5).

Initial $\mathrm{SAR}_{\mathrm{e}}$ at the Naughton site was 1 in all lysimeters and varied little with depth (Fig. 6). By 1989 the SAR in the 0 - to $0.15-\mathrm{m}$ depth had increased substantially in all lysimeters. The $\mathrm{SAR}_{\mathrm{e}}$ was slightly higher than the $\mathrm{SAR}_{\mathrm{i}}$ in lysimeters receiving the $0.1 \mathrm{~S} \mathrm{~m}^{-1}$ irrigation water and was slightly lower than the $\mathrm{SAR}_{i}$ in lysimeters receiving the $0.34 \mathrm{~S} \mathrm{~m}^{-1}$ irrigation water (Fig. 6). The SAR $_{\mathrm{e}}$ decreased and the magnitude of this decrease was greater in lysimeters receiving the $0.1 \mathrm{~S} \mathrm{~m}^{-1}$ irrigation water than in lysimeters receiving the $0.34 \mathrm{~S} \mathrm{~m}^{-1}$ irrigation water and was more pronounced at the lowest irrigation level than at the two higher irrigation levels (Fig. 6). In lysimeters receiving the lowest level of irrigation, $\mathrm{SAR}_{\mathrm{e}}$ in 1989 was similar to the initial value below $0.5 \mathrm{~m}$. In lysimeters receiving the two higher levels of irrigation the increase in $\mathrm{SAR}_{e}$ was evident to a depth of $1 \mathrm{~m}$ or more (Fig. 6).

The $\mathrm{SAR}_{\mathrm{e}}$ in 1991 and 1992 was similar throughout the profile to that in 1989 (Fig. 6). This similarity suggests that under the climatic conditions experienced during those years, the amount of salt being added in irrigation water and that being leached in drainage had reached an equilibrium. The general pattern was a $S_{A} R_{e}$ similar to that of the irrigation water in the 0 - to $0.25-\mathrm{m}$ depth, a slight increase in $\mathrm{SAR}_{e}$ in the 0.25 - to $0.5-\mathrm{m}$ depth, and a decline in $S_{\text {SAR }}$ with depth to a value similar to the $1986 \mathrm{SAR}_{\mathrm{e}}$ (Fig. 6).

As with $\mathrm{EC}_{\mathrm{e}}$ the above-normal precipitation received in 1993 (Fig. 4) resulted in lower SAR values in the 0 - to $0.15-\mathrm{m}$ depth of all treatments (Fig. 6). Below 0.5 $m$ the $S R_{e}$ declined but was higher than that observed in 1991 and 1992 (Fig. 6). These results suggest that the high precipitation leached salts lower in the sampled soil profile.

The changes in $\mathrm{EC}_{\mathrm{e}}$ (Fig. 5) and $\mathrm{SAR}_{\mathrm{e}}$ (Fig. 6) exhibited at the Naughton site resulted in significant year $X$ water quality, and year $x$ irrigation amount interactions in the statistical analysis (Table 2). Changes in salinity of these soils were dependent on the amount and quality

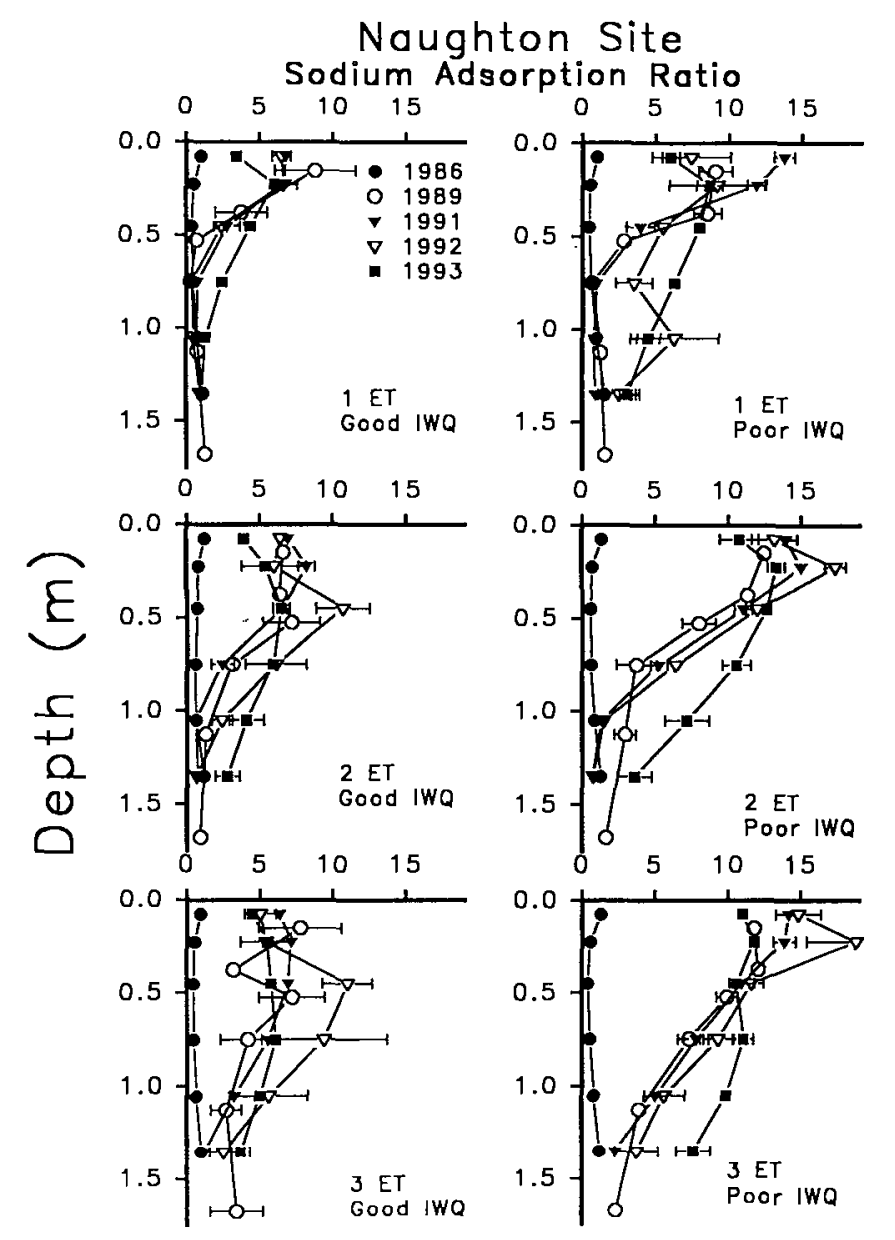

Fig. 6. Saturated paste extract sodium adsorption ratio (SAR) as a function of soil depth for lysimeters at the Menoken site receiving water inputs equal to one, two, and three times the calculated evapotranspiration (ET) rate as either good irrigation water quality (good IWQ: electrical conductivity $[\mathrm{EC}]=0.1 \mathrm{~S} \mathrm{~m} \mathrm{~m}^{-1}$ and $\mathrm{SAR}=$ 4) or poor irrigation water quality (poor IWQ: $\mathrm{EC}=0.34 \mathrm{~S} \mathrm{~m}^{-1}$ and SAR $=16$ ).

of irrigation water applied (Table 2). The magnitude of the change in salinity varied among sampling periods, due to yearly differences in climatic conditions. The variation with depth resulted from textural heterogeneity within the profile (Table 1).

\section{DISCUSSION}

Uncertainty about the effect of irrigation on soil properties has limited development of supplemental irrigation for soils with fine-textured subsoils. As salts in the irrigation water are added to these soils, the concentration of $\mathrm{Ca}, \mathrm{Mg}$, and $\mathrm{Na}$ increase, resulting in an increase in $\mathrm{EC}_{\mathrm{e}}$. When the salt concentration becomes great enough, minerals will begin to form. The first minerals likely to form in the soil systems studied here are calcite and gypsum. Arndt and Richardson (1989) found that these minerals began to form at a salt concentration corresponding to an $\mathrm{EC}_{\mathrm{e}}$ of $0.4 \mathrm{~S} \mathrm{~m}^{-1}$. As additional salts are added, calcite and gypsum form and the concentration of $\mathrm{Ca}$ no longer increases while that of $\mathrm{Na}$ and $\mathrm{Mg}$ continue to increase, resulting in an increase in $\mathrm{EC}_{e}$ and $\mathrm{SAR}_{\mathrm{e}}$. 
Salinity changes observed in the lysimeters demonstrate that the drainage capacity of these soils is sufficient, and addition of water in excess of that required by the crop can be applied to ensure leaching of salts. The leaching potential of precipitation was demonstrated in the spring of 1992 at the Menoken site when the effect of snowmelt and spring precipitation was measured and during 1993 at the Naughton site when above-normal precipitation was received and little supplemental irrigation was required. Precipitation received in the spring prior to initiation of irrigation was very effective at leaching salts from the soil profile, reducing the $\mathrm{EC}_{\mathrm{e}}$ in the spring to $25 \%$ of that measured in the fall (Fig. 2). Precipitation received after initiation of irrigation will dilute salts present in the irrigation water.

Sodicity increases are more persistent and are not greatly changed by snowmelt and precipitation leaching (Fig. 3). If poor quality irrigation water is used, sodicity may become a problem. An increase in sodicity may result in a degradation of soil physical properties. Loss of soil tilth is occasionally observed by producers utilizing groundwater for supplemental irrigation in North Dakota (J.L. Richardson, personal communication). Amelioration of sodicity problems will require a chemical treatment. Either $\mathrm{CaSO}_{4}$ or $\mathrm{CaCl}_{2}$ could potentially be used as an amendment to correct sodicity (U.S. Salinity Laboratory Staff, 1954). As stated above, $\mathrm{CaCO}_{3}$ and $\mathrm{CaSO}_{4}$ begin to form naturally when the $\mathrm{EC}_{\mathrm{e}}$ approaches $0.4 \mathrm{~S}$ $\mathrm{m}^{-1}$ in these soils (Arndt and Richardson, 1989). Under these conditions, the solubility of added $\mathrm{CaSO}_{4}$ would be low, limiting the effectiveness of gypsum as an amendment. Calcium chloride has a much higher solubility than gypsum and has been demonstrated to be an effective amendment in sodic soils in North Dakota (Sandoval et al., 1972).

Increases in salinity in the lysimeters were not sufficient to cause a reduction in alfalfa yield (Wienhold and Trooien, 1995, unpublished data). The $\mathrm{EC}_{\mathrm{e}}$ threshold for alfalfa yield reductions is $0.2 \mathrm{~S} \mathrm{~m}^{-1}$ (Maas, 1986). In lysimeters receiving the $0.34 \mathrm{~S} \mathrm{~m}^{-1}$ irrigation water, this threshold value was exceeded (Fig. 2 and 5). However, $\mathrm{EC}_{\mathrm{e}}$ was usually measured in the fall of the year when soil profile salt concentrations were greatest. As stated above, leaching by snowmelt and spring precipitation greatly reduces the amount of salt present in the soil profile.

Supplemental irrigation of alfalfa is a viable management strategy in the Northern Great Plains. Drainage capacity for several soils with fine-textured subsoils has been demonstrated to be sufficient for well-managed irrigation (Trooien and Reichman, 1993). Here we have shown that changes in salinity should not be sufficient to reduce alfalfa yields if attention is paid to water quality.
When $0.34 \mathrm{~S} \mathrm{~m}^{-1}$ irrigation water (similar to shallow groundwater in North Dakota) was used, sufficient water could be applied to leach salts below the root zone and prevent salinization. However, sodicity did increase and $\mathrm{CaCl}_{2}$ addition may be required to prevent loss of soil tilth. When good quality irrigation water (similar to Missouri River water) was used, salt accumulation and changes in sodicity were slight.

\section{ACKNOWLEDGMENTS}

We thank John Bullinger and Wallace Sellner for maintaining the field sites and the Burleigh County Water Resources District for supplying equipment and access to the sites.

\section{REFERENCES}

Arndt, J.L., and J.L. Richardson. 1989. Geochemistry of hydric soil salinity in a recharge-throughflow-discharge prairie-pothole wetland system. Soil Sci. Soc. Am. J. 53:848-855.

Chang, C., G.C. Kozub, and D.C. McKay. 1985. Soil salinity status and its relation to some of the soil and land properties of three irrigation districts in southern Alberta. Can. J. Soil Sci. 65:189193.

Costa, J.L., L. Prunty, B.R. Montgomery, J.L. Richardson, and R.S. Alessi. 1991. Water quality effects on soils and alfalfa: II. Soil physical and chemical properties. Soil Sci. Soc. Am. J. 55:203209.

Doering, E.J., L.C. Benz, and G.A. Reichman. 1986. Internal drainage of fine-textured alluvial subsoils in North Dakota. Trans. ASAE 29:517-521

Jensen, M.E., D.C.N. Robb, and C.E. Franzoy. 1970. Scheduling irrigations using climate-crop-soil data. J. Irrig. Drain. Div. Am. Soc. Civ. Eng. 96:25-38.

Leitch, J.A., J.F. Baltezore, R.G. Johnson, and R.C. Coon. 1991. A reevaluation of Garrison Diversion Unit irrigation. Project Rep. Garrison Diversion Conservancy District, Carrington, ND.

Lundstrom, D.R., and E.C. Stegman. 1983. Irrigation scheduling by the checkbook method. North Dakota Ext. Publ. AE-792. North Dakota State Univ., Fargo.

Maas, E.V. 1986. Salt tolerance of plants. Appl. Agric. Res. 1:1226.

Prunty, L., B.R. Montgomery, and M.D. Sweeney. 1991. Water quality effects on soils and alfalfa: I. Water use, yield, and nutrient concentration. Soil Sci. Soc. Am. J. 55:196-202.

Rhoades, J.D. 1982. Soluble salts. p. 167-179. In A.L. Page et al. (ed.) Methods of soil analysis. Part 2. 2nd ed. Agron. Monogr. 9. ASA and SSSA, Madison, WI.

Sandoval, F.M., J.J. Bond, and G.A. Reichman. 1972. Deep plowing and chemical amendment effect on a sodic claypan soil. Trans. ASAE 15:681-684, 687.

SAS Institute. 1990. SAS/STAT guide for personal computers. Version 6 ed. SAS Inst., Cary, NC.

Trooien, T.P., and G.A. Reichman. 1990. Hydraulic conductivity of till subsoil in North Dakota. Tran. ASAE 33:1492-1496.

Trooien, T.P., and G.A. Reichman. 1993. Internal drainage under irrigation of two slowly permeable subsoils of the northern Great Plains. Trans. ASAE 36:709-715.

U.S. Salinity Laboratory Staff. 1954. Diagnosis and improvement of saline and alkali soils. USDA Agric. Handb. 60. U.S. Gov. Print. Office, Washington, DC.

U.S. Department of Interior, Bureau of Reclamation. 1993. Drainage manual. U.S. Gov. Print. Office, Washington, DC. 